\title{
BILATERAL INTERNAL ILIAC ARTERY LIGATION-A BOON FOR SEVERE POST PARTUM HEMORRHAGE
}

Vinay Naithani, Jitendra Solanki.

1. Professor. Department of Cardio Thoracic and Vascular Surgery, RNT Medical College, Udaipur. Rajasthan.

2. Resident, RNT Medical College, Udaipur. Rajasthan.

\section{CORRESPONDING AUTHOR}

Dr. Vinay Naithani,

Govt. Quarters II/238,

OTC Scheme Charak Marg,

Udaipur.

E-mail: drvinaynaithani@yahoo.co.in

Ph: 00919829114544

ABSTRACT: OBJECTIVE: To evaluate utility and outcome of emergency bilateral internal iliac artery ligation (BIIAL), as life saving measure in severe post partum hemorrhage (PPH).

MATERIAL AND METHOD: Between June2003 to May 2012, a total of twenty four patients of severe PPH were managed with emergency BIIAL with or without hysterectomy. All patients were in shock and we were called directly in operation theatre $(0 \mathrm{~T})$. The Patients were managed post operatively in obstetric intensive care unit (ICU) with ventilator and inotropic supports. RESULT: We had one (4.16\%) mortality with successful outcome in 23(95.83\%) patients. In 8 patients (33.33\%) hysterectomy has already been performed before we could intervene. One (4.16\%) patient develop pulmonary embolism but was saved. CONCLUSION: Emergency BIIAL is an life saving procedure and should be learned and managed by all surgeon in severe PPH

KEY WORDS: Post Partum hemorrhage (PPH), Bilateral internal iliac artery ligation (BIIAL), Obstetric ICU

INTRODUCTION: Ligation of internal iliac artery was first performed by Kelly for carcinoma uterus with success rate of $95 \%$, without any major complication. ${ }^{(1)}$ In 1952 , Waters ${ }^{(2)}$ reported BIIAL as anatomically sound, physiologically rational and surgically possible method to control $\mathrm{PPH}$. Severe PPH is one of the most common cause of morbidity and mortality related to child birth. More than one third of maternal mortality has been attributed to it. Prompt identification of the cause and initiation of treatment is the best way of effective management. Oxytocin, Prostaglandins, hysterectomy, selective vascular embolisation has been performed as treatment of choice. We prefer BIIAL as simple effective and life saving procedure in all cases of severe $\mathrm{PPH}$.

METHOD: This study was performed in Department of cardiothoracic and vascular surgery at Maharana Bhupal Government Hospital, Ravindra Nath Tagore medical college, Udaipur (Rajasthan, India). Between June 2003 to May 2012, 24 patients who had torrential bleeding per vaginum due to severe $\mathrm{PPH}$, we were called directly in operation theatre for active intervention as last measure. BIIAL was performed in all patients as an emergency procedure. Table 1 shows the characteristics of our patients regarding age, parity, pre and postoperative status. All patients were dealt with continuous oxytocin infusion, heavy inotropic support (Dopamine, 
Noradrenalin) and two to four units of blood transfusions were already been given before procedure.

PROCEDURE: The abdomen was explored by extending Phennesteil incision vertically mid line nearly up to umbilicus leading to " $\mathrm{T}$ " shape incision. This gives better visibility in approaching common iliac artery bifurcation in presence of bulky uterus and edematous surrounding tissue. Packing and retraction of all surrounding bowel loops were done. Retroperitoneal dissection was done, ureter was visualized and retracted .The internal iliac artery was carefully dissected and separated from fragile internal iliac vein. The artery was then lifted and looped around twice with No.2 Sutupack suture. Double ligation of the artery was carried out without division on both sides. Retro peritoneal layer was closed over vessel. No drain was kept and abdomen closed in layers. Vaginal packing was done in all cases.

Postoperatively patients were managed in ICU on ventilator, continuous oxytocin infusion, heavy inotropic supports (Dopamine and Noradrenalin) along with blood, FFP and Platelet transfusion as per need. The inotropic drugs were tapered slowly between 48 to $72 \mathrm{hrs}$. All patients were weaned off ventilator between $24-48$ hours. Vaginal packing was removed after $24 \mathrm{hrs}$ and changed daily. Infection prophylaxis with broad spectrum antibiotics was given. All patients were discharged between 12-18 days from Post natal ward. Late discharge of some patients is policy to avoid any late complications as patients belongs to remote tribal zone.

RESULTS: During the period June 2003 to May 2012, total number of deliveries conducted in Department of Gynecology and obstetrics were 141853. In all 24 patients with severe PPH, uterine atony was the cause of illness.The patients included in this series were between age20$40 \mathrm{yrs}$ with mean age of 26.5yrs. Most of the Patients were between 20-30 years and were in active phase of fertile period. 6 (25\%) patients were multipara while remaining 18(75\%) patients were prime Para. In 8 cases (33.33\%) hysterectomy has already been performed by gynecologist to control of hemorrhage but still patients were bleeding through vault. In patients where hysterectomy had been performed 5 patients were prime Para while 3 patients were multi Para. Out of 24 patients, 23 (95.83\%) patients were successfully managed by BIIAL and were discharged between $12-18$ days from postnatal ward. We had mortality of one $(4.16 \%)$ patient due to irreversible shock after 12 hours .One patient had bleeding from iliac vein during dissection which was repaired. One patient suffered from pulmonary embolism on $5^{\text {th }}$ post operative day. This patient was shifted in cardiology ICU and treated successfully with Injection heparin infusion and non invasive CPAP. There was no ischemic complication post operatively due to BIIAL.

DISCUSSION: Bilateral Internal iliac artery ligation in intractable PPH is an effective life saving method and hysterectomy can often be avoided. BIIAL has been used in life threatening obstetrical, gynecological or general surgery hemorrhage. Prophylactic ligation to reduce blood loss has been used in radical procedure as Wertheim hysterectomy, radical vulvectomy ${ }^{(3)}$ and abdominoperineal resection of carcinoma rectum.(4)Bilateral internal iliac artery ligation does not hamper further reproductive function.(5) Bilateral internal iliac artery ligation does not produce pelvic ischemia, it merely converts the high pressure arterial flow in the pelvic arteries into a sluggish venous like flow allowing clotting and homeostasis; and successful pregnancies have been reported after the procedure.(6)However complications like buttock claudication, 
bladder and bowel necrosis have been reported mainly in atherosclerotic patients who did not have good collateral circulation .

Both absorbable(7) and non-absorbable (silk) suture material has been used. In our series we have used non absorbable no. 2 sutupack double ligation in all cases to avoid any chance of recurrent bleeding which may happen with absorbable sutures. Successful full term pregnancies following BIIAL has been reported and collateral circulation is sufficient to allow adequate blood supply

In our study,8(33.33\%)patients underwent hysterectomy before we were called for ligation. On the other hand in patients where BIIAL has been performed alone none required hysterectomy hence we feel BIIAL could have saved the hysterectomy, if not in all but at least in few patients if it was performed early to control bleeding. SHEIKH\&FADUL (8) and EVANS (9) reported $29 \%$ and $57 \%$ patients respectively required hysterectomy after ligation of bilateral internal iliac artery ligation. Mukherjee et al(10) performed 36 cases of internal iliac artery ligation with success rate of $83.3 \%$ in 6 yr. In our series the success rate is $93.83 \%$ may be due to small patients group as compare to Mukherjee series.

One patient had bleeding from iliac vein during dissection. Hence one should be cautious while separating iliac artery from fragile vein in presence oedematous surrounding tissue and bulky uterus.

One patient in our series has developed pulmonary embolism on $5^{\text {th }}$ post operative day. This was diagnosed with symptom of sudden dyspnoea followed by urgent ECG, $\mathrm{x}$ - ray chest and 2D Echo evaluation. Patient was managed with heparin infusion, non invasive CPAP. Patient recovered after 3 days of ICU management. So one should be cautious in managing these sick recumbent patients as mortality by this cause can be avoided if diagnosed early. This further emphasizes the importance of obstetric ICU management in post operative period as early diagnosis and management of postoperative complications might have saved most of our patients.

Various modalities of treatment has been described for PPH. Medical management required judicious use of oxytocin or methyl ergotamine and recently misoprostal in oral and rectal route has been successfully used. Hysterectomy, internal iliac artery ligation isolated or bilateral, stepwise devascularisations of uterus and compression sutures of uterus are found effective(11). Recently angiographic embolisation(12)is required if medical management failed. Angiographic embolisation is least invasive but requires shifting to radiology room, special instrumentation and trained personnel. This is not feasible in very sick patients. In our centre this facility is not available.

CONCLUSION: We conclude that bilateral internal iliac artery ligation is a good option in controlling severe PPH. It is a simple, rapid and effective life saving operation and should be done before taking decision to do hysterectomy in intractable $\mathrm{PPH}$, thus saving fertility and menstrual function. It is easy to perform with no added morbidity or mortality.

\section{REFERENCES:}

1. Kelly HA. Ligation of internal iliac arteries for hemorrhage in hysterectomy for carcinoma uteri. Bull Johns Hopkins Hosp1894; 5:53

2. 2 Water EG. Surgical management of postpartum hemorrhage with particular reference to ligation of uterine arteries. Am J Obstet Gynecol 1952; 64; 1143-8 
3. Paraskevaid E, Noelkel, Afrisibim. Internal iliac artery ligation in obstetrics gynecology. Eur. J. Obstet. Report Biol.1993; 52:71-75

4. Tajes RV. Ligation of the hypo gastric arteries and its complications inthe resection of cancer of the rectum. Am J Gasteroentrol 1956; 26:612-616.

5. Oleszczuk D, Cebulak K, Skert A et al. Long term observation of patients after bilateral ligation of internal iliac arteries. Ginekol pol 1995; 66:533-6.

6. Papp Z,Sztanyi QL, Szabo Invoay. Successful pregnancy after B/L internal iliac artery ligation monitored by coloured Doppler imaging. Ultasound Obstet Gynaecol 1996; 7:211-212.

7. Burecell R.C. Physiology of internal iliac artery ligation .J Obestet Gynaecology Br.C"wealth 1968; 75:642-651.

8. Mohamed Ahmed Ali El Sheikh et al. Bilateral internal iliac artery ligation in obstetric haemorrhage. Yemen Medical Journal 2000; 3:109.

9. Evans S, McShane. The efficacy of internal iliac artery ligation in obstetric hemorrhage.Surg. Gynecol. Obstet.1985;166:253

10. Mukherjee P, Das C, Mukherjee G et al .Emergency internal iliac ligation for obstetrical and gynecological hemorrhage. Jobstet.Gynaecol. Ind 2002; 52:147-149.

11. Mukherjee P, Biswas P. Compression suture in post partum hemorrhage. J Obstet Gynaecol Ind 2003; 53: 158-9.

12. Vedantham S, Goddwin SC, McLucas B, Mohr G. Uterine artery embolization: An underused method of controlling pelvic hemorrhage. Am J Obstet Gynecol 1997; 176:938-48. 
Table 1: Details of 24 patients

\begin{tabular}{|c|c|c|c|c|c|c|c|c|}
\hline S.NO. & Age & $\begin{array}{c}\text { PARIT } \\
\text { Y. }\end{array}$ & $\begin{array}{l}\text { Causative } \\
\text { factor }\end{array}$ & Pre BIIAL Rx & $\begin{array}{c}\text { Time } \\
\text { Before } \\
\text { BIIAL }\end{array}$ & $\begin{array}{c}\text { Hysterectom } \\
\mathrm{y}\end{array}$ & complication & $\begin{array}{c}\text { Hospita } \\
\text { l stay }\end{array}$ \\
\hline 1 & $29 \mathrm{yr}$ & Multi & $\begin{array}{l}\text { Uterine } \\
\text { atony }\end{array}$ & $\begin{array}{l}\text { Continuous syntocin } \\
\text { infusion, blood } \\
\text { transfusion,inotropic } \\
\text { support with } \\
\text { ventilated }\end{array}$ & $1 \mathrm{hr}$ & Yes & $\begin{array}{l}\text { Pulmonary } \\
\text { embolism }\end{array}$ & 16days \\
\hline 2 & $28 y r$ & primi & " & “ & $3 \mathrm{hr}$ & " & No & 17days \\
\hline 3 & $21 \mathrm{yr}$ & Primi & " & & $1 \mathrm{hr} 30 \mathrm{mts}$ & No & " & 12days \\
\hline 4 & $22 \mathrm{yr}$ & Primi & " & & $2 \mathrm{hr}$ & " & " & 12days \\
\hline 5 & $32 \mathrm{yr}$ & Multi & “ & $"$ & $2 \mathrm{hr}$ & “ & “ & 13days \\
\hline 6 & $21 \mathrm{yr}$ & Primi & “ & “ & $3 \mathrm{hr}$ & “ & “ & 12days \\
\hline 7 & $25 \mathrm{yr}$ & Primi & " & “ & $4 \mathrm{hr}$ & " & “ & 12days \\
\hline 8 & $23 \mathrm{yr}$ & Primi & $"$ & $"$ & $1 \mathrm{hr}$ & “ & “ & 13days \\
\hline 9 & $33 y \mathrm{r}$ & Multi & “ & “ & $2 \mathrm{hr} 30 \mathrm{mts}$ & $"$ & “ & 14days \\
\hline 10 & $20 \mathrm{yr}$ & Primi & $"$ & “ & $3 \mathrm{hr}$ & Yes & “ & 18days \\
\hline 11 & $23 \mathrm{yr}$ & Primi & $"$ & “ & $2 \mathrm{hr}$ & No & " & 15days \\
\hline 12 & $27 \mathrm{yr}$ & Primi & “ & “ & $2 \mathrm{hr}$ & Yes & “ & 16days \\
\hline 13 & $26 \mathrm{yr}$ & Primi & “ & " & $1 \mathrm{hr}$ & No & “ & 12days \\
\hline 14 & $21 \mathrm{yr}$ & Primi & “ & " & $4 \mathrm{hr}$ & $"$ & “ & 13days \\
\hline 15 & $40 \mathrm{yr}$ & Multi & $"$ & “ & $3 \mathrm{hr}$ & Yes & " & 17days \\
\hline 16 & $25 \mathrm{yr}$ & Primi & $"$ & “ & $1 \mathrm{hr}$ & No & $"$ & 13days \\
\hline 17 & $24 \mathrm{yr}$ & Primi & " & “ & $2 \mathrm{hr}$ & $"$ & “ & 18days \\
\hline 18 & $28 \mathrm{yr}$ & Primi & $"$ & $"$ & $2 \mathrm{hr}$ & " & " & 12days \\
\hline 19 & $25 \mathrm{yr}$ & Primi & $"$ & “ & $4 \mathrm{hr}$ & Yes & “ & 16days \\
\hline 20 & $26 y r$ & Primi & $"$ & “ & $1 \mathrm{hr}$ & $"$ & " & 14days \\
\hline 21 & $26 y r s$ & primi & " & “ & $1 \mathrm{hr}$ & No & “ & 11days \\
\hline 22 & 33yrs & Multi & $"$ & " & $1 \mathrm{hr} 40 \mathrm{mts}$ & yes & “ & 12days \\
\hline 23 & $\begin{array}{l}27 \\
\text { Yrs }\end{array}$ & Primi & “ & “ & $1 \mathrm{Hr} 30 \mathrm{mts}$ & No & $\begin{array}{l}\text { Iliac vein } \\
\text { bleeding }\end{array}$ & 13days \\
\hline 24 & $31 y r s$ & Multi & " & $"$ & $2 \mathrm{hr}$ & No & No & 15days \\
\hline
\end{tabular}

